DOI: $10.30519 /$ ahtr. 899626

\begin{tabular}{lr}
\hline Advances in Hospitality and Tourism Research (AHTR) & 2021 \\
An International Journal of Akdeniz University Tourism Faculty & Vol. 9 (2) \\
ISSN: 2147-9100 (Print), 2148-7316 (Online) & $368-389$ \\
Webpage: http://www.ahtrjournal.org/ & \\
\hline
\end{tabular}

\title{
SMALL HOTEL LOCATION SELECTION PROBLEM: THE CASE OF CAPPADOCIA
}

\author{
Tekiner KAYA ${ }^{1}$ \\ Department of International Trade and Logistics, Nevsehir Hacı Bektaş Veli University, Turkey \\ ORCID: 0000-0001-6136-5028
}

\begin{abstract}
Identifying an appropriate location is one of the most significant factors in determining the success of a facility. This paper focuses on the selection of the most appropriate small hotel location in inner Cappadocia, based on seven destination-specific criteria. The Pivot Pairwise Relative Criteria Importance Assessment (PIPRECIA) and Additive Ratio Assessment (ARAS) methodology is utilized to obtain the relative criteria weights and the final ranking of six alternative small hotel locations. The results indicate that the most important factors in small hotel location selection in Cappadocia are revenue per available room (REVPAR) potential, investment amount and view of hot air balloon flights. Goreme and Uchisar are identified as the most appropriate locations for small hotel investment in the region.
\end{abstract}

\section{Article History}

Received 19 March 2021

Revised 6 July 2021

Accepted 17 August 2021

Published online 30 Sep. 2021

Keywords

small hotel location selection

Cappadocia

PIPRECIA

ARAS

\section{INTRODUCTION}

The Facility Location Problem (FLP) models are utilized to solve location selection problems in variety of business environment to take advantage in competition. Based on the FLP model description and content, hotel location is very important factor in tourism industry that affects facility revenue. Luo and Yang (2016) found that hotel location is directly related to occupancy and average daily rate, which means that it is also directly related to the hotel revenue. It is important to identify an appropriate location for a hotel because of the relocating and reconfiguring is costly and complex process (Urtasun \& Gutiérrez, 2006). Since hotel industry is a service industry, the effective location selection in this sector plays an important role on attracting visitors and achieving success amid extreme

\footnotetext{
${ }^{1}$ Address correspondence to Tekiner Kaya (Ph.D.), Department of International Trade and Logistics, Faculty of Business Administration and Economics, Nevsehir Hacı Bektaş Veli University, Turkey. Email: tekiner.kaya@nevsehir.edu.tr
} 
competition (Yang et al., 2012). Location is a factor that strongly influences travellers' hotel selections (Lewis \& Chambers, 1989; Rivers et al., 1991; Chu \& Choi, 2000).

In the existing literature, studies have examined the factors that contribute to hotel location selection, including parking, transportation, proximity to tourist attractions, public service infrastructure, economic environment, development status of the region, agglomeration effect (It is considered to attenuate with distance when a decreasing impact is obtained the further away the rings) are from the location (Combes \& Gobillon, 2015), and accessibility. Studies have also found that location selection criteria may vary by hotel type. For instance, Kalnins and Chung (2004) present that differing hotel star ratings were associated with different locations. Specifically, Yang et al. (2012) found that unbranded hotels and economy hotels (branded) are likely to be located close to upscale brand hotels. In addition, branded hotels operating in upscale segment are generally located in the same area. Accessibility criteria are also very important for luxury hotels, which tend to have central locations, whereas service diversification and proximity to restaurants are important factors for downscale hotels.

Small hotels are properties that are independently managed by the owners, who are referred to as tourism entrepreneurs (Sa et al., 2020). In Cappadocia, there are more than 400 small hotels with an average of 13 rooms (Nevsehir Provincial Directorate of Culture and Tourism reports, 2019). Cappadocia is located in a volcanic area; therefore, these hotels have cave rooms. The majority of the small hotels are family-run businesses, which are popular among visitors because they offer an opportunity to talk to residents and learn about the local culture and traditions. Baker et al. (2000) found that the large majority of small hotels have fewer than 100 rooms; however, the present study defines small hotels as those with fewer than 30 rooms. The reason for this discrepancy is that hotels with more than 30 rooms likely provide less opportunity for the managers to communicate with their guests in a facility located in a leisure or cultural tourism destination.

The Cappadocia region includes many destinations; the present study focuses on inner Cappadocia, which includes six sub-destinations in which travellers may seek accommodation: Urgup, Goreme, Uchisar, Avanos, Mustafapasa and Ortahisar (see Figure 1). In recent decades, the region has attracted investors' attention because of its high potential for the hospitality industry. 


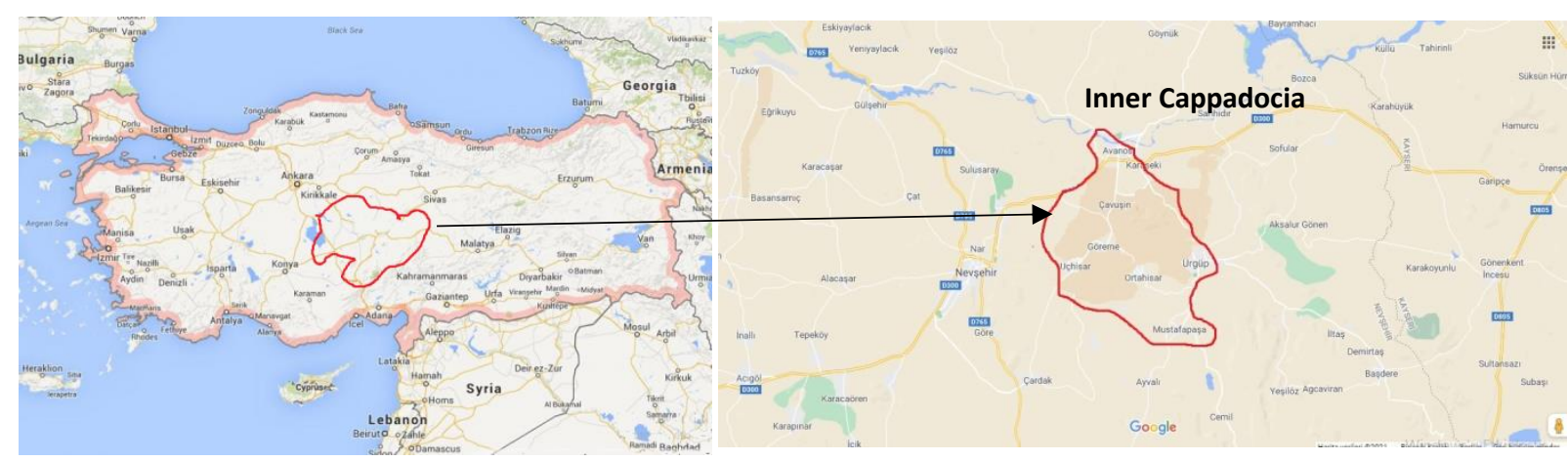

Figure 1. Overview of the study area

The prioritization of hotel locations requires a comprehensive analysis of potential locations and gathering information about the target visitor group of tourists (Yang et al., 2014). There are three primary destinations in the inner Cappadocia region that include the majority of small hotels: Goreme, Urgup and Uchisar. Additionally, there are three subdestinations: Avanos, Mustafapasa and Ortahisar. All sub-destinations are in inner Cappadocia and are close to one another; however, each offers unique strengths and location-specific characteristics - such as room rate, investment amount, cave room quality, food and commercialization - that complicate investment decisions. The present study aims to identify the most appropriate small hotel location selection in Cappadocia by utilizing PIPRECIA (Pivot Pairwise Relative Criteria Importance Assessment) and ARAS (Additive Ratio Assessment Method) methodology. Hence, the criteria-based performance of sub-destinations of Cappadocia is going to be exposed for investors. Decision-making techniques have been applied for solving many business problems including the tourism sector such as Popovic and Mihajlovic (2018), Panahi et al. (2015), Pulido-Fernández et al. (2014), and Briedenhann (2009). Since hotel location selection decisions are very complex and costly (Urtasun \& Gutiérrez, 2006), the methodology utilized in this study may shed light on decision-makers, policymakers, and investors.

The paper is organized as follows. A review of empirical studies and models that have analysed the hotel location selection problem is provided in section 2. Section 3 describes the two-stage PIPRECIA and ARAS methodology. The study scope, determinants of the hotel location selection process and data are presented in Section 4. Finally, the results are discussed in section 5, and conclusions are drawn in Section 6. 


\section{LITERATURE REVIEW}

Investing in and focusing on a hotel's location in a new destination is important because the location of the hotel can help to increase profitability and market share (Chou et al., 2008). The process of choosing a hotel location is complex, and the multidisciplinary nature of the problem has been extensively studied in the existing literature. For example, Luo and Yang (2016) and Yang et al. (2014) found that sufficient hotel location is directly related to the average daily rate (ADR) and occupancy rate, which in turn contributes to a high revenue per available room (REVPAR). In two studies of customer satisfaction, Sim et al. (2006) and Lee \& Jang (2011) found that visitors who stay in a hotel that is in a good location are more satisfied.

The existing literature regarding the problem of hotel location selection has focused on three main topics: demand, ADR potential, and customer satisfaction. Studies have generally focused on the determinants of hotel location that lead to profitability. For example, Molina-Azorin et al. (2010) and Peiró-Signes et al. (2014) have analysed the effect of hotel location choice on hotel financial performance. Puciato (2016) has examined the effect of hotel location on the cost of running the hotel. Additionally, Adam and Amuquandoh (2014) have analysed the hotel location selection problem from a managerial point of view. Researchers have emphasized the importance of transportation and public security in the design of a hotel. For example, Luo and Yang (2016) argue that competitive advantage is an essential factor in location selection in the hotel industry. Shoval et al. (2011) found that hotel location had a dramatic impact on the behaviour of tourists such as iconic tourism nodes and icon attractions. Finally, Yang et al. (2014) discuss the hotel location choice problems in terms of supply-demand perspective considering preferences of visitors, socioeconomic development of regions, distance to tourist attractions and convenience of transportation. However, no studies have yet focused on the hotel location selection problem among small hotels.

Multi-criteria decision-making (MCDM) models have been utilized to solve real-world location choice problems, including KEMIRA-M (Krylovas et al., 2014), ANP (Wu et al., 2010), TOPSIS (Huang \& Peng, 2012), DEMATEL (Liu et al., 2012), PROMETHEE (Kaya et al., 2013), ELECTRE (Botti \& Peypoch, 2013), -OWA (ordered weighted averaging) (Jeong et al., 2014) and DEA (Shirouyehzad et al., 2013). Adam and Amuquandoh (2014) assessed and analysed the factors that contributed to hotel location selection in Ghana using Principal Component Analysis (PCA). Additionally, Ilgin et 
al. (2015), Zavadskas et al. (2014), Govindan et al. (2015), Mardani et al. (2015) and Popovic et al. (2019) summarized the models that have been utilized in hotel location selection problems. The most utilized MCDM models are regression models, simultaneous equation models, individual evaluation models, hotel success models, statistical prediction models, factor analysis models, qualitative and cartography models, analytical hierarchy process (AHP) models and multi-dimensional models.

PIPRECIA and ARAS methodologies are used in many studies in the literature. For example, Stevic et al. (2021) used novel rough PIPRECIA methodology which is the extended version of the classical model, to determine the weight of 18 criteria of companies in the forestry industry. In another study, Memis et al. (2020) prioritized transportation risks via fuzzy PIPRECIA. Stevic et al. (2018) also used a fuzzy PIPRECIA model to evaluate information technology conditions for warehouses system. Dalic et al. (2020a) utilized PIPRECIA to measure the logistics performance of corporations. Tomasevic et al. (2020) used the fuzzy PIPRECIA model to determine the importance level of criteria for the introduction of highperformance computing in the Danube.

Some studies use PIPRECIA as a part of the multi-model approach. Dalic et al. (2020b) utilized fuzzy PIPRECIA and internal rough SAW model to select the green supplier. Veskovic et al. (2020) utilized fuzzy PIPRECIA and fuzzy EDAS to determine the best variant of the rail operator. Biswas (2020) used an integrated MCDM framework which consists of MABAC (Multi-Attributive Border Approximation Area Comparison), CoCoSo (Combined Compromise Solution) and PIPRECIA which is used to weights of criteria that are used to measure supply chain performance. Popovic et al. (2019) presented the extended version to PIPRECIA which is called PIPRECIA-E. Bakir et al. (2020) proposed a hybrid MCDM model based on the integration of PIPRECIA and MAIRCA (Multi Attributive Ideal-Real Comparative Analysis). PIPRECIA is utilized to determine the criteria weights on the evaluation of the operational performance of airlines. While PIPRECIA method is used to define the criteria weight, WASPAS method is applied for the ranking of alternatives. Dobrosavljevic et al. (2020) used PIPRECIA and FUCOM (full consistency method) to prioritize the most influential dimensions affecting the establishment of business process management. Fuzzy PIPRECIA is used to obtain more accurate criteria weight. Markovic et al. (2020) developed a novel integrated model that consists of fuzzy PIPRECIA and CRITIC (criteria importance through intercriteria correlation). Nedeljković et al. (2021) used PIPRECIA and MABAC (Multi-Attributive Border Approximation Area Comparison) 
models to rank the supplier. PIPRECIA is utilized to weight criteria and sub-criteria. In the tourism industry, Stanujkic and Karabasevic (2018) examined the website quality in the hotel industry via PIPRECIA and WASPAS. Jaukovic Jocic et al. (2020) used PIPRECIA and ARAS methods to select the most appropriate e-learning course. In this study, PIPRECIA is used to determine the weights of the criteria for the assessment of the quality of e-learning material.

On the other hand, ARAS is utilized to solve many MCDM problems such as the selection and ranking of alternatives. Karabasevic et al. (2015, 2016) utilized the SWARA-ARAS hybrid model for personnel selection. Similarly, Karabasevic et al. (2018) used ARAS to software testing methods. In the study by Nweze and Achebo (2021), the mechanical properties are optimized by using COPRAS (Complex proportional assessment) and ARAS methodologies. Furthermore, SWARA and fuzzy-ARAS integrated model is utilized to evaluate oil and gas well drilling project by Dahooie et al. (2018).

\section{MODEL}

In addition to mathematical modelling, MCDM methods can aid managers in selecting the best location for hotel accommodations. The FLP model can analyse a set of possible locations to determine which options are best located for hotel facilities. This model can consider various criteria (e.g., cost or distance) to determine which location best serves a set of "customer" or demand points (Farahani et al., 2012).

The two-stage PIPRECIA and ARAS methodology were selected for this study because of the strengths of each analytical tool. Specifically, the PIPRECIA methodology weights criteria by ranking, which leads to accurate results, and the ARAS methodology has been utilized to solve a variety of location selection problems in the literature, including logistics centres, waste storage area, and shopping centre location selection problems. In addition, the computational procedure of ARAS is very simple compared to other MCDM methods such as PROMETHEE and TOPSIS. To maintain simplicity, ensure accuracy and applicability, a two-stage PIPRECIA and ARAS methodology is utilized in this study. The flow chart of the model is presented in Figure 2. 


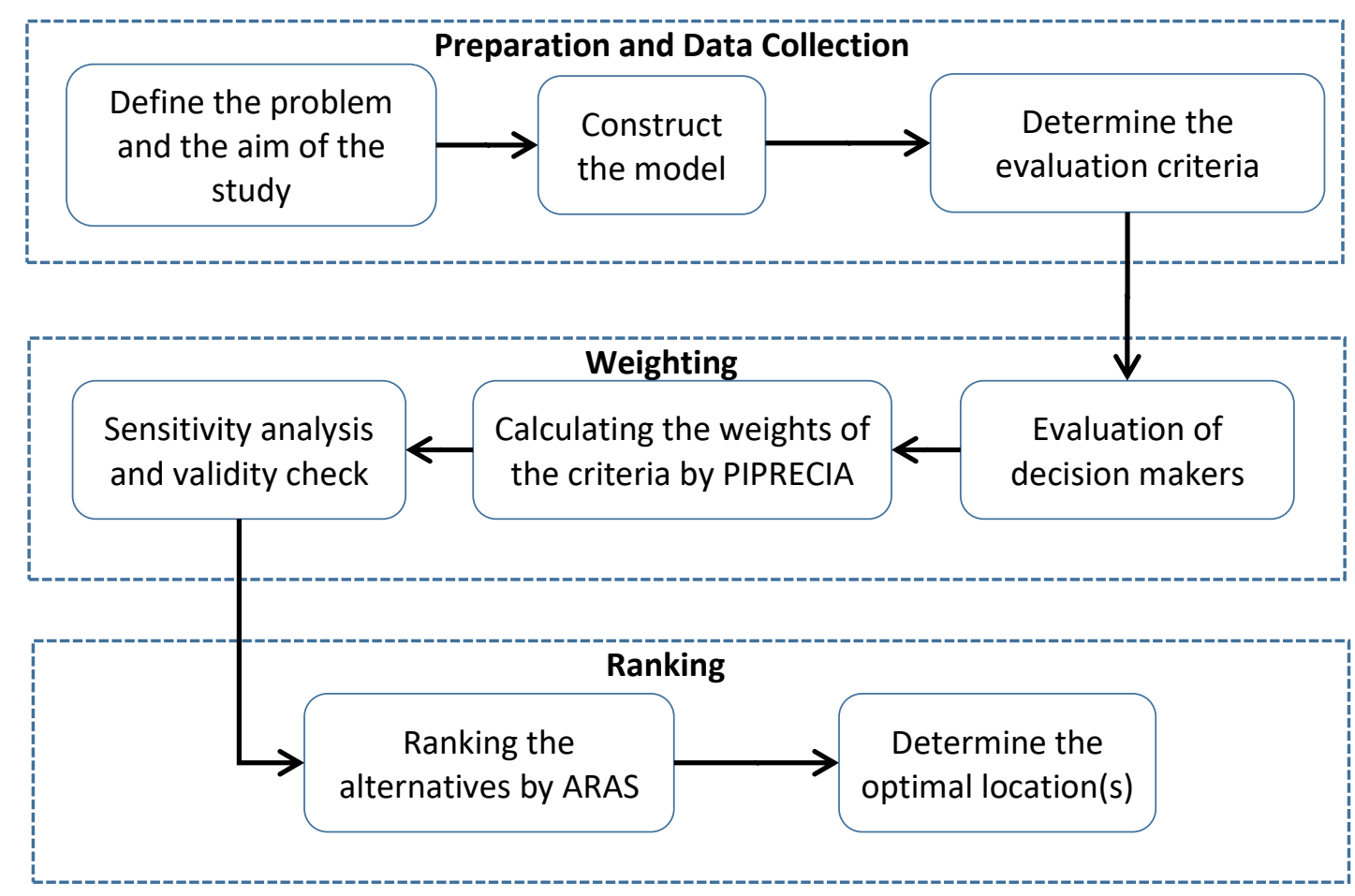

Figure 2. Proposed two-stage conceptual flow for the selection of small hotel location

The reason behind the utilizing two-stage PIPRECIA and ARAS methodology on the selection of small hotel locations is that PIPRECIA makes the comparison process easier in group decisions while determining the weight of criteria for various cases in the tourism industry such as restaurant selection, evaluation of touristic projects, and hotel websites. Besides, it allows checking the consistency of decision-makers' evaluations through correlation coefficients. On the other hand, ARAS method yields acceptable, relatively accurate and reasonable results in ranking. It has been utilised to solve selection problems in many areas such as supplier selection, equipment selection, and personnel selection.

\section{PIPRECIA}

Many weighting methods used in the literature based on the evaluation of experts or mathematical algorithm applications to the decision matrix. The PIPRECIA method, first proposed by Stanujkic et al. (2017), can anticipate the relative weight of criteria that have been determined by experts in a specific area. The experts can consult with one another in PIPRECIA; therefore, this method can be utilized to solve problems that involve compromise and that require accurate results. The model is evolved from the SWARA methodology which requires the evaluation criteria to be ranked according to their estimated significance (Vesković et al., 2018). 
However, PIPRECIA eliminated this procedure and makes the comparison process easier in group decisions (Popović \& Mihajlović, 2018). Besides, PIPRECIA can check the consistency of decision-makers evaluations through correlation coefficients (Stanujkic et al., 2019).

Experts play a crucial role in evaluating factors and determining relative weights within the PIPRECIA methodology. Relative priorities of each factor are remarked by each expert and the final rates of criteria are obtained. The most important criteria for effective decision-making that guide experts are experience and information. While the lowest rank refers to the least significant criterion, the highest rank refers to the most significant criterion in PIPRECIA method. The average of the ranked values is analysed to determine the final priority rankings (Keršuliene \& Turskis, 2011).

According to Adam and Amuquandoh (2014), location selection decisions have a multi-dimensional perspective which covers hotel characteristics (such as the number of rooms, year of establishment, type of ownership, and category of the hotel) and location factors such as physical site and neighbourhood characteristics and transportation factors considered by the owners of the hotel. The criteria used in the location choice process are identified through an extensive literature review. Determining the relative weight of hotel location selection criteria is an important concern for experts and investors, and different experts may attribute different weights to each of the evaluation criteria. The PIPRECIA methodology provides accurate criteria ratings for decision-making teams that may face difficulty in reconciling the relative weight of criteria. The process by which the relative weighting of hotel location selection criteria is determined utilizing the PIPRECIA method includes the following steps (Stanujkic et al., 2017; Popović \& Mihajlović, 2018):

Step 1. Rank the set of evaluation criteria determined in a descending order based on expected significances.

Step 2. Experts express the comparative importance of criterion $j$ concerning the previous $(j-1)$ criterion $\left(\mathrm{s}_{j}\right)$ starting from the second criterion.

$S_{j}=\left[\begin{array}{lll}>1, & \text { if } & C_{j}>C_{j-1} \\ 1, & \text { if } & C_{j}=C_{j-1} \\ <1, & \text { if } & C_{j}<C_{j-1}\end{array}\right]$

Step 3. Calculate the $k_{j}$ coefficient for each criterion as follows: 
$k_{j}=\left[\begin{array}{ll}1 & j=1 \\ 2-S_{j} & j>1\end{array}\right]$

Step 4. Determine the initial weighting factors $q_{j}$ for criterion $j$ as follows:

$q_{j}=\left[\begin{array}{ll}1 & j=1, \\ \frac{q_{j-1}}{k_{j}} & j>1 .\end{array}\right]$

Step 5. Determine the relative weighting factors of the evaluation criteria as follows:

$w_{j}=\frac{q_{j}}{\sum_{k=1}^{n} q_{k}}$

( $n$ denotes the total number of criteria and $w_{j}$ denotes the relative weight of criterion $j$ ).

Step 6. Calculate the final weight of each criterion $(W j)$ as follows:

$W j=\frac{1}{K} \sum_{k=1}^{K} w_{j}^{k}$

\section{ARAS}

The ARAS methodology which is first proposed by Zavadskas and Turskis (2010), which has been utilized to solve different type of problems in a variety of areas, including the ranking of institutions, personnel selection, site selection, supplier selection and equipment selection. In a study of the ARAS method, Ghenai et al. (2020) found that its application to a wide range of problems and growth in popularity can be attributed to the simple, straightforward steps of the method. The ARAS method yields acceptable, relatively accurate and reasonable results in ranking. Zavadskas and Turskis (2010) present ARAS methodology by utilizing six step procedures:

Step 1. Calculate the optimal performance rating. To create a decision matrix, experts grade the relative performance of the $a$-th alternative compared to the $j$-th criterion. The variable $r$ denotes the number of experts. The experts' overall evaluation grade for each $j$-th criterion alternative is calculated as the geometric mean grade as follows:

$x_{a j}=\left(\prod_{k=1}^{r} x_{a j}^{k}\right)^{1 / r}$

The optimal performance rating indicates the best performing criterion among the available alternatives and is calculated as follows: 
$x_{o j}=\left\{\begin{array}{ll}\max _{a} x_{a j} ; & j \in \varphi_{\max } \\ \min _{a} x_{a j} ; & j \in \varphi_{\min }\end{array}\right\}$,

Where $x_{o j}$ is the $j$-th criterion optimal performance rating, whereas $\varphi_{\max }$ and $\varphi_{\min }$ denotes the benefit criterion and the set of cost criteria respectively.

Step 2: Calculate the normalized decision matrix by using the equation:

$$
x_{a j, N}=\left\{\begin{array}{ll}
\frac{x_{a j}}{\sum_{a=1}^{m} x_{a j}} & j \in \varphi_{\max } \\
\frac{1 / x_{a j}}{\sum_{a=1}^{m} \frac{1}{x_{a j}}} & j \in \varphi_{\min }
\end{array}\right\}
$$

In equation (8), $x_{a j}$ denotes the $a$-th alternative normalized performance rating in relation to the $j$-th criterion, $a=0,1, \ldots m$.

Step 3. Calculate the weighted normalized decision matrix. The calculated weights of the evaluation criteria are applied to the normalized decision matrix. By using the following formula, the weights are calculated:

$$
v_{a j}=w_{i j}^{r} x_{a j, N}
$$

The variable $v_{a j}$ denotes the weighted normalized performance rating of the $a$-th alternative compared to the $j$-th criterion.

Step 4. For each alternative, calculate the overall performance index for each $a^{\text {th }}$ alternative $\left(S_{a}\right)$ by using the equation:

$$
S_{a}=\sum_{j=1}^{n} v_{a j}
$$

Step 5. Calculate the degree of utility for each alternative. The relative performance of each alternative compared to the best alternative is defined as the degree of utility of each alternative $\left(Q_{a}\right)$. A higher value of $Q_{a}$ (see equation 10) indicates a higher priority, and a $Q_{a}$ value of 1 indicates the optimal alternative. The variable $S_{o}$ denotes the index of the optimal alternative's overall performance.

$$
Q_{a}=\frac{s_{a}}{S_{o}}
$$

Step 6. Rank the alternatives in upward order, $Q_{a}$, and select the most efficient alternative. 


\section{PROBLEM: SELECTION OF SMALL HOTEL LOCATION IN CAPPADOCIA}

Cappadocia is one of the most popular cultural tourism destinations in Turkey. It is famous for its small cave hotels which offer a unique experience. One of the aims of these hotels is "not to make their guests experience a hotel atmosphere but to host them like they are at home".

The region has a wide variety of tourist attractions, such as hot air balloon flights, valleys, underground cities, and natural beauties. Thus, investors are inclined to buy and restore the old cave houses. However, there are complex criteria for hotel location selection in Cappadocia, and therefore the problem can be modelled as a MCDM problem.

\section{Data}

The data used for this study was collected from interviews with six professional experts from Cappadocia. Demographic characteristics of experts are presented in Table 1.

Table 1. Demographic characteristics of experts

\begin{tabular}{cccc}
\hline Education & Age & $\begin{array}{c}\text { Experience in Tourism } \\
\text { Sector (years) }\end{array}$ & Position \\
\hline B.S & 71 & 32 & General Manager / Hotel Owner \\
M.S & 39 & 10 & Manager \\
B.S & 35 & 12 & Manager \\
PhD & 41 & 11 & Engineer \\
B.S & 55 & 30 & General Manager / Travel Agency Owner \\
B.S & 39 & 12 & Specialist \\
\hline
\end{tabular}

The collected data are presented in the results section. As part of the ARAS process, each expert's criterion-based evaluation (1-10) was gathered, and average scores were calculated to create an initial decision matrix.

\section{Hotel Location Selection Criteria}

Cappadocia has unique natural and cultural specifications; therefore, interviews with specialists from the region were conducted to determine Cappadocia-specific location criteria. Additionally, the most used criteria for hotel location selection problems were identified in the literature. 
Many empirical researches have examined factors for selecting the right hotel location, including characteristics of the facility (Yang et al. 2014), agglomeration effects (Luo \& Yang, 2016; Marco-Lajara et al., 2016, 2017), close connections to tourist attractions (Yang et al., 2012), ease of transportation ( $\mathrm{Li}$ et al., 2015), land use type (Fang et al., 2019), the infrastructure of public service (Yang et al., 2012), urban development (Shoval \& Cohen-Hattab, 2001), land cost (Baum \& Haveman, 1997; Egan \& Nield, 2000), and economic environment (Urtasun \& Gutiérrez, 2006; RigallI-Torrent et al., 2011). Bull (1998) has compiled these criteria into three areas that influence the selection of hotel locations: physical site characteristics, distance from certain places, and neighbourhood characteristics. Additionally, Pan (2002) has divided the criteria for hotel location selection problems into six categories: base station suitability, public facilities, flexibility of space, traffic convenience, application of certain regulations, fine visual perception.

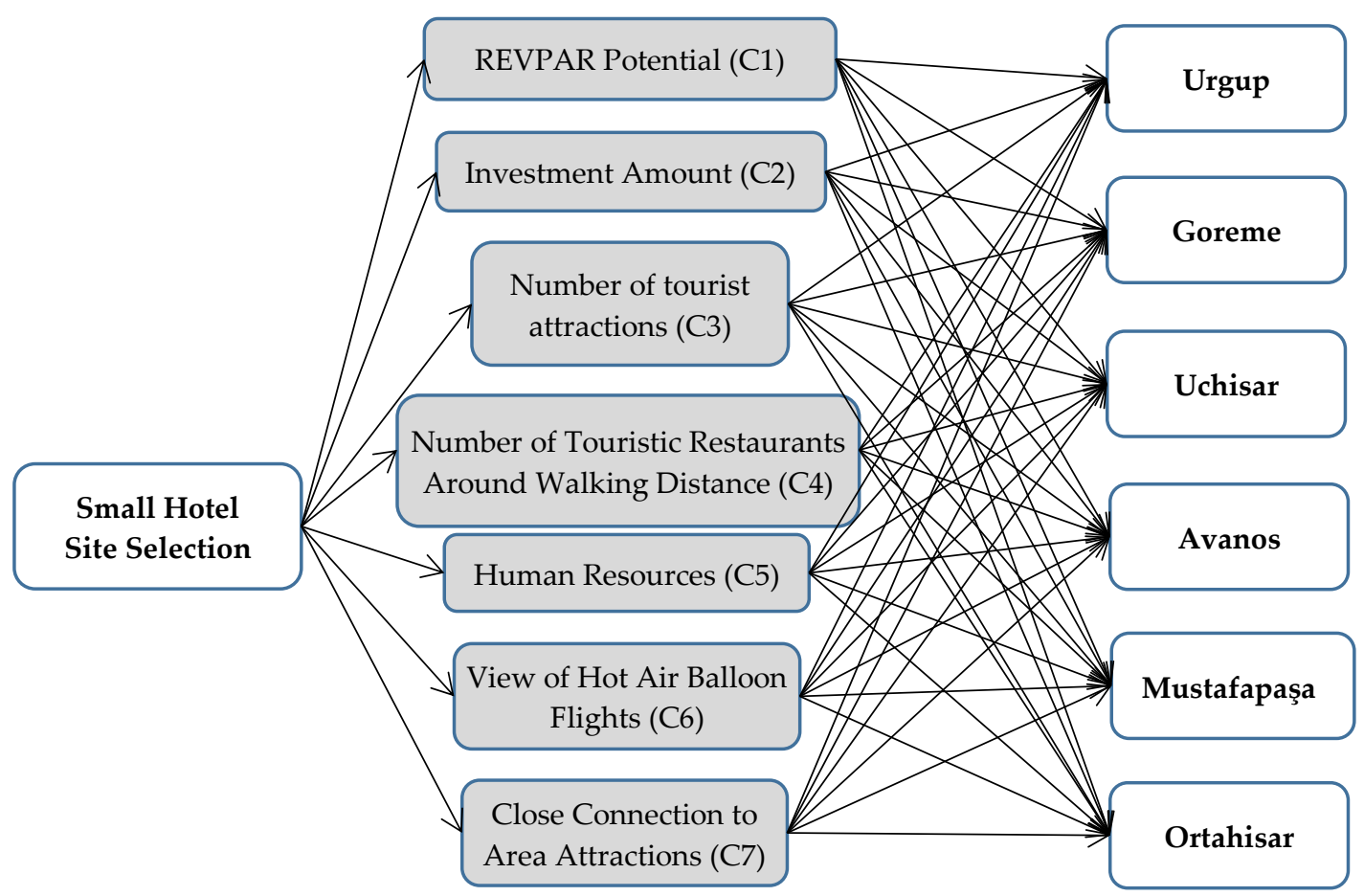

Figure 3. Alternative small hotel locations and evaluation criteria

The criteria that were used for small hotel location selection in this study are summarized in Figure 3. These are determined based on the Cappadocia dynamics as described by experts, as well as the empirical studies mentioned above. The criteria in Figure 3 were grouped into five categories as presented in Table 2. 
Table 2. Criteria used in small hotel location selection problem

\begin{tabular}{cc}
\hline Criteria & Category \\
\hline FC1 & Economic \\
\hline FC2 & Tourist attractions \\
\hline FC3 & Sociocultural \\
\hline FC6 & Human capital \\
\hline FC4 & Urban development \\
\hline FC5 & \\
\hline FC7 & \\
\hline
\end{tabular}

The first two evaluation criteria, REVPAR and investment cost, are the main indicators of the investment decisions in accommodation facilities that introduce income and expense respectively. The number of tourist attractions and restaurants around the hotel is two of the most important criteria that directly affect the hotel performance as mentioned above. The fifth criterion, human resources, is crucial for service quality and facility management. The quality and the quantity of the employees in the region is also critical for the tourism industry. One of the region-specific criteria is the view of hot air balloon flights. For the last five years, demand changed towards the hotels that have a view of balloon flights. So, one of the important criteria affecting the demand and revenue is the view of the balloon flight of the hotel. The final criterion utilized in this study is a close connection to area attractions which is categorized in FC7. Since there are many touristic points in Cappadocia, visitors want to reach these areas easily and fast. The closer the hotels are to these points, the more the customer preference shifts to these hotels.

\section{RESULTS}

Based on the PIPRECIA weighting methodology, the six experts ranked the seven criteria and relative weight of each criterion was determined. Table 3 presents the relative weighting factors of the criteria $\left(\mathrm{s}_{j}\right)$.

Table 3. Relative weighting factors of the criteria based on the responses obtained from six experts $(S j)$

\begin{tabular}{ccccccc}
\hline \multirow{2}{*}{ Ranking } & & \multicolumn{5}{c}{ Sj } \\
& Exp-1 & Exp-2 & Exp-3 & Exp-4 & Exp-5 & Exp-6 \\
\hline FC1 & & & & & & \\
FC2 & 0.70 & 1.30 & 0.80 & 1.20 & 0.40 & 0.70 \\
FC3 & 0.20 & 0.20 & 0.40 & 0.20 & 0.30 & 0.30 \\
FC4 & 1.10 & 0.90 & 0.20 & 0.20 & 0.30 & 0.40 \\
FC5 & 1.25 & 1.60 & 0.30 & 1.40 & 1.40 & 1.30 \\
FC6 & 0.70 & 0.80 & 1.50 & 1.40 & 1.30 & 1.10 \\
FC7 & 0.30 & 0.30 & 0.20 & 0.30 & 0.20 & 0.15 \\
\hline
\end{tabular}


Based on equation (2), the comparative importance coefficient for each criterion $\left(k_{j}=\mathrm{s}_{j}+1\right)$ was determined (see Table 4$)$.

Table 4. Comparative importance coefficient $\left(k_{j}\right)$ for each criterion

\begin{tabular}{|c|c|c|c|c|c|c|}
\hline \multirow{2}{*}{ Ranking } & \multicolumn{6}{|c|}{$\boldsymbol{k}_{j}$} \\
\hline & Exp-1 & Exp-2 & Exp-3 & Exp-4 & Exp-5 & Exp-6 \\
\hline FC1 & 1.00 & 1.00 & 1.00 & 1.00 & 1.00 & 1.00 \\
\hline FC2 & 1.30 & 0.70 & 1.20 & 0.80 & 1.60 & 1.30 \\
\hline FC3 & 1.80 & 1.80 & 1.60 & 1.80 & 1.70 & 1.70 \\
\hline FC4 & 0.90 & 1.10 & 1.80 & 1.80 & 1.70 & 1.60 \\
\hline FC5 & 0.75 & 0.40 & 1.70 & 0.60 & 0.60 & 0.70 \\
\hline FC6 & 1.30 & 1.20 & 0.50 & 0.60 & 0.70 & 0.90 \\
\hline FC7 & 1.70 & 1.70 & 1.80 & 1.70 & 1.80 & 1.85 \\
\hline
\end{tabular}

Next, the initial weighting factor $q_{j}$ was calculated for each criterion. The relative weight of each criterion was determined through the normalization of the initial weights. Table 5 presents the $q_{j}$ weights and the relative weight for each criterion $j\left(w_{j}\right)_{\text {. }}$

Table 5. The initial weight of each criterion $\left(q_{j}=\left[q_{j}-1\right] / k_{j}\right)$ and relative weights of the evaluation criteria $\left(w_{j}\right)$

\begin{tabular}{|c|c|c|c|c|c|c|c|c|c|c|c|c|}
\hline \multirow[b]{2}{*}{ Criterion } & \multicolumn{2}{|c|}{ Exp-1 } & \multicolumn{2}{|c|}{ Exp-2 } & \multicolumn{2}{|c|}{ Exp-3 } & \multicolumn{2}{|c|}{ Exp-4 } & \multicolumn{2}{|c|}{ Exp-5 } & \multicolumn{2}{|c|}{ Exp-6 } \\
\hline & $q_{j}$ & $\boldsymbol{w}_{j}$ & $q_{j}$ & $\boldsymbol{w}_{j}$ & $q_{j}$ & $w_{j}$ & $q_{j}$ & $w_{j}$ & $q_{j}$ & $w_{j}$ & $q_{j}$ & $\boldsymbol{w}_{j}$ \\
\hline FC1 & 1.00 & 0.25 & 1.00 & 0.12 & 1.00 & 0.30 & 1.00 & 0.18 & 1.00 & 0.30 & 1.00 & 0.28 \\
\hline $\mathrm{FC} 2$ & 0.77 & 0.19 & 1.43 & 0.18 & 0.83 & 0.25 & 1.25 & 0.22 & 0.63 & 0.19 & 0.77 & 0.21 \\
\hline FC3 & 0.43 & 0.10 & 0.79 & 0.10 & 0.52 & 0.16 & 0.69 & 0.12 & 0.37 & 0.11 & 0.45 & 0.13 \\
\hline FC4 & 0.47 & 0.12 & 0.72 & 0.09 & 0.29 & 0.09 & 0.39 & 0.07 & 0.22 & 0.06 & 0.28 & 0.08 \\
\hline FC5 & 0.63 & 0.16 & 1.80 & 0.22 & 0.17 & 0.05 & 0.64 & 0.11 & 0.36 & 0.11 & 0.40 & 0.11 \\
\hline FC6 & 0.49 & 0.12 & 1.50 & 0.18 & 0.34 & 0.10 & 1.07 & 0.19 & 0.51 & 0.15 & 0.45 & 0.12 \\
\hline FC7 & 0.29 & 0.07 & 0.88 & 0.11 & 0.19 & 0.06 & 0.63 & 0.11 & 0.29 & 0.08 & 0.24 & 0.07 \\
\hline
\end{tabular}

The final weight of each criterion $\left(W_{j}\right)$ is determined as described above in equation (5). Table 6 presents each criterion's final weight. Based on results, the most critical factor in small hotel location selection is the REVPAR potential of the location, however, the investment amount criterion is the second in importance. The third most important criterion is the ability to view hot air balloon flights from the location. This criterion is specific to Cappadocia, where hot air balloon flights are a popular and unique experience for visitors.

As described in the literature review, determinants of hotel location have been investigated in many studies (Egan \& Nield, 2000; Urtasun \& Gutiérrez, 2006; Chou et al., 2008). The final weights of the criteria in this study are not consistent with the literature due to the unique dynamics of 
Cappadocia, including the lack of (or limited) agglomeration effect, view of balloon flights variable and geographical structure of alternative locations (i.e., having cave rooms or views). The results indicate that the experts' criteria rankings were primarily based on financial inputs and outputs.

Table 6. Overall weights for criteria

\begin{tabular}{lc}
\hline \multicolumn{1}{c}{ Final Ranking } & $\boldsymbol{w}_{j}$ \\
\hline FC1 - REVPAR Potential & 0.23 \\
FC2 - Investment Amount & 0.20 \\
FC6 - View of Hot Air Balloon Flights & 0.15 \\
FC5 - Human resources & 0.13 \\
FC3 - Number of Tourist Attractions & 0.13 \\
FC7 - Close Connection to Area Attractions & 0.08 \\
FC4 - Number of touristic Restaurants Around Walking & 0.08 \\
\hline
\end{tabular}

After figuring out the weight of the criterion, the reliability of decision-makers' responses is checked by Kendall's $\tau$ Coefficient Correlation because of the small data set. In table 7 minimum correlation coefficient is $54 \%$ which may be assumed the weights are consistent.

Table 7. Consistency index for decision-makers responses (Spearman's Rank Correlation Coefficient)

\begin{tabular}{|c|c|c|c|c|c|c|}
\hline & DM1 & DM2 & DM3 & DM4 & DM5 & DM6 \\
\hline DM1 & - & $74.8 \%$ & $62.6 \%$ & $69.0 \%$ & $54.0 \%$ & $74.0 \%$ \\
\hline DM2 & & - & $76.0 \%$ & $58.0 \%$ & $75.0 \%$ & $63.0 \%$ \\
\hline DM3 & & & - & $56.2 \%$ & $82.0 \%$ & $87.0 \%$ \\
\hline DM4 & & & & - & $77.0 \%$ & $79.0 \%$ \\
\hline DM5 & & & & & - & $85.0 \%$ \\
\hline DM6 & & & & & & - \\
\hline
\end{tabular}

\section{Sensitivity Analysis}

Changes in the weight of the criteria may significantly affect the rankings. To ensure robustness and stability, sensitivity analysis is required in MCDM methods (Yazdani et al., 2019). In this part, the stability and validity of the study are checked via sensitivity analysis. 10 different scenario sets are generated based on the assignment of criterion weights to each criterion by keeping minimum and maximum weights constant. Scenario-based ranking changes are presented in Figure 4. Sensitivity analysis results show that no drastic changes in ranking were observed except very small changes between fifth and sixth place. 


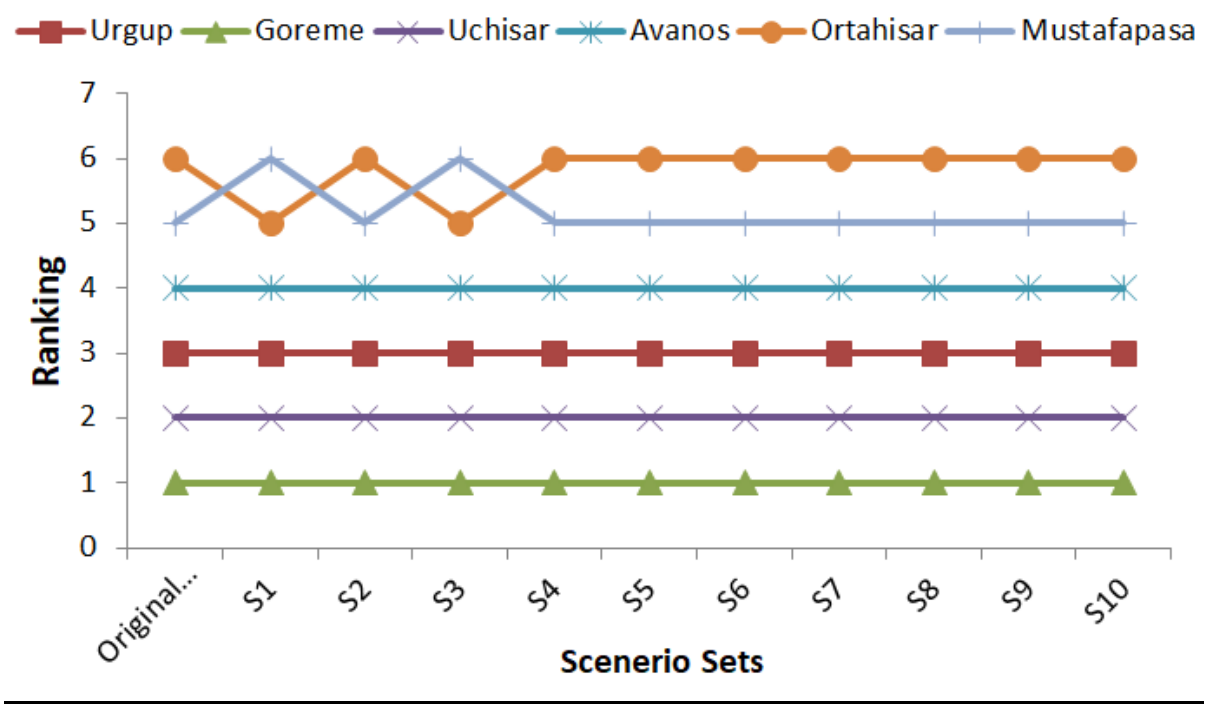

Figure 4. Change in rankings based on scenarios.

The present evaluation of small hotel locations involved six experts who ranked seven criteria. The relative weight of each criterion is calculated by the PIPRECIA methodology, and a decision matrix was generated as the first step of the ARAS methodology by using 1 to 10 Likert scale experts' evaluations (see Table 8).

Table 8. Initial decision matrix

\begin{tabular}{cccccccc}
\hline Clternatives & FC1 & FC2 & FC3 & FC4 & FC5 & FC6 & FC7 \\
\hline Optimal & Max & Min & Max & Max & Max & Max & Max \\
\hline Weight & $\mathbf{0 . 2 3}$ & $\mathbf{0 . 2 0}$ & $\mathbf{0 . 1 3}$ & $\mathbf{0 . 0 5}$ & $\mathbf{0 . 1 3}$ & $\mathbf{0 . 1 5}$ & $\mathbf{0 . 0 8}$ \\
\hline A0 & $\mathbf{1 0}$ & $\mathbf{2}$ & $\mathbf{1 0}$ & $\mathbf{1 0}$ & $\mathbf{1 0}$ & $\mathbf{1 0}$ & $\mathbf{1 0}$ \\
\hline Urgup & 4.46 & 4.34 & 6.75 & 8.75 & 7.75 & 1.10 & 7.40 \\
Goreme & 8.42 & $\mathbf{7 . 4 7}$ & 10.00 & 9.00 & 7.50 & 8.70 & 9.30 \\
Uchisar & 8.75 & 9.05 & 6.75 & 5.50 & 7.38 & 9.00 & 8.90 \\
Avanos & 2.29 & 3.02 & 4.75 & 4.50 & 788 & 2.50 & 6.95 \\
Ortahisar & 3.63 & 3.37 & 5.00 & 2.50 & 7.25 & 1.05 & 5.85 \\
Mustafapasa & 3.31 & 3.91 & 7.25 & 4.25 & 7.13 & 0.70 & 5.50 \\
\hline
\end{tabular}

Table 9. Weighted normalized decision matrix and the overall performance index $\left(S_{a}\right)$

\begin{tabular}{ccccccccc} 
Criterion & FC1 & FC2 & FC3 & FC4 & FC5 & FC6 & FC7 & Sa \\
\hline Alternatives & & & & & & & & \\
\hline A0 & $\mathbf{1 0}$ & $\mathbf{2}$ & $\mathbf{1 0}$ & $\mathbf{1 0}$ & $\mathbf{1 0}$ & $\mathbf{1 0}$ & $\mathbf{1 0}$ & - \\
\hline Urgup & 0.026 & 0.025 & 0.016 & 0.016 & 0.018 & 0.005 & 0.011 & $\mathbf{0 . 1 1 8}$ \\
Goreme & 0.049 & 0.015 & 0.024 & 0.017 & 0.017 & 0.038 & 0.014 & $\mathbf{0 . 1 7 4}$ \\
Uchisar & 0.051 & 0.012 & 0.016 & 0.010 & 0.017 & 0.040 & 0.014 & $\mathbf{0 . 1 6 0}$ \\
Avanos & 0.012 & 0.037 & 0.011 & 0.008 & 0.018 & 0.011 & 0.011 & $\mathbf{0 . 1 0 8}$ \\
Ortahisar & 0.021 & 0.033 & 0.012 & 0.005 & 0.017 & 0.005 & 0.009 & $\mathbf{0 . 1 0 1}$ \\
Mustafapasa & 0.019 & $\mathbf{0 . 0 2 8}$ & $\mathbf{0 . 0 1 7}$ & $\mathbf{0 . 0 0 8}$ & $\mathbf{0 . 0 1 6}$ & 0.003 & 0.008 & $\mathbf{0 . 1 0 1}$ \\
\hline
\end{tabular}


Prior to normalizing and weighting the decision matrix, the investment amount criterion (FC2) was adjusted, and the direction of optimization changed to the maximum because it is a cost criterion. Table 9 presents the weighted normalized decision matrix.

Finally, for each alternative $\left(Q_{a}\right)$, the degree of utility and the ranking of the evaluated small hotel location alternatives were determined (see Table 10). The hotel location alternatives were ranked in ascending order according to $Q_{a}$. Based on the results, Goreme is ranked as the first location among the alternatives, followed by Uchisar and Urgup.

Table 10. Results of the final ranking of alternatives

\begin{tabular}{cccc}
\hline Alternatives & $\boldsymbol{S}_{a}$ & $\boldsymbol{Q}_{a}$ & Ranking \\
\hline A0 & 0.16 & 1 & - \\
Goreme & 0.17 & 1.07 & 1 \\
Uchisar & 0.16 & 0.98 & 2 \\
Urgup & 0.12 & 0.72 & 3 \\
Avanos & 0.11 & 0.66 & 4 \\
Ortahisar & 0.10 & 0.62 & 5 \\
Mustafapasa & 0.10 & 0.62 & 5 \\
\hline
\end{tabular}

\section{CONCLUSION}

The selection of a facility location from a choice of alternative locations is a typical MCDM problem, the solution of which can offer strategic results for corporations. The decision of appropriate location choice is of paramount importance for decision-makers since relocation and reconfiguration would be extremely costly and contain complex processes.

The hospitality industry in Turkey is an important component of the Turkish economy because the sector is one of the country's leading export channels. Cappadocia plays an important role as a leading cultural tourism destination, and it has strong tourism diversity capabilities with unique geographical and cultural qualities of the region.

Based on the presented framework, as well as the example of its use in small hotel location selection, the two-stage methodology utilized in this study is easily practical and adaptive. Based on a set of selection criteria, it can be utilized to rank hotel location alternatives efficiently. The results indicate that Goreme is the most appropriate small hotel location and Uchisar is the second most appropriate location. The overall performance of Goreme and Uchisar are similar and close to one another, whereas the third most appropriate location, Urgup, is far away. This finding indicates 
that investors should first focus allocating budget for developing sites in Goreme and Uchisar. Based on the final rankings, Avanos is not considered a worthwhile alternative for a small hotel location in Cappadocia. However, it is ranked fourth by a small weight difference and is ranked above two famous villages, Ortahisar and Mustafapasa. Therefore, Avanos may hold potential for small hotel locations that involve relatively low investment costs.

The study has some limitations. The first one is the lack of detailed data such as occupation ratios of locations. It is just considered based on experts' experience. By consolidation of the data of the small hotels in subdestinations may overcome this problem. Second, the criteria used in this type of study directly affect the rankings. So, criteria may be expanded in future studies considering the dynamics of destinations and periods. Finally, the study considers only the relevant research period. In future research, the two-stage model can be used in different facility location selection problems that include location-specific criteria.

\section{ACKNOWLEDGEMENT}

I would like to thank particularly insightful reviewers for many helpful comments, suggestions and contributions.

\section{REFERENCES}

Adam, I., \& Amuquandoh, F. E. (2014). Hotel characteristics and location decisions in Kumasi Metropolis, Ghana. Tourism Geographies, 16(4), 653-668.

Baker, S., Bradley, P., \& Huyton, J. (2000). Principles of Hotel Front Office Operations. London: Cengage Learning EMEA.

Bakir, M., Akan, Ş., Kiraci, K., Karabasevic, D., Stanujkic, D., \& Popovic, G. (2020). Multiplecriteria approach of the operational performance evaluation in the airline industry: Evidence from the emerging markets. Rom. J. Econ. Forecast, 23, 149.

Baum, J. A., \& Haveman, H. A. (1997). Love thy neighbor? Differentiation and agglomeration in the Manhattan hotel industry, 1898-1990. Administrative Science Quarterly, 304-338.

Biswas, S. (2020). Measuring performance of healthcare supply chains in India: A comparative analysis of multi-criteria decision making methods. Decision Making: Applications in Management and Engineering, 3(2), 162-189.

Botti, L., \& Peypoch, N., (2013). Multi-criteria ELECTRE method and destination competitiveness. Tourism Management Perspectives, 6, 108-113.

Briedenhann, J. (2009) Socio-cultural criteria for the evaluation of rural tourism projects a Delphi consultation. Current Issues in Tourism, 12(4), 379-396.

Bull, A. O. (1998). The effects of location and other attributes on the price of products which are place-sensitive in demand. Unpublished doctoral dissertation, Griffith University, Australia. 
Chou, T. Y., Hsu, C. L., \& Chen, M. C. (2008). A fuzzy multi-criteria decision model for international tourist hotels location selection. International Journal of Hospitality Management, 27(2), 293-301.

Chu, R. K., \& Choi, T. (2000). An importance-performance analysis of hotel selection factors in the Hong Kong hotel industry: a comparison of business and leisure travellers. Tourism management, 21(4), 363-377.

Combes, P. P., \& Gobillon, L. (2015). The Empirics of Agglomeration Economies. Handbook of Regional and Urban Economics, 5, 247-348.

Dahooie, J. H., Zavadskas, E. K., Abolhasani, M., Vanaki, A., \& Turskis, Z. (2018). A novel approach for evaluation of projects using an interval-valued fuzzy additive ratio assessment (ARAS) method: a case study of oil and gas well drilling projects. Symmetry, 10(2), 45.

Đalic, I., Ateljevic, J., Stevic, Z., \& Terzic, S. (2020a). An Integrated SWOT-Fuzzy PIPRECIA model for analysis of competitiveness in order to improve logistics performances. Facta Universitatis, Series: Mechanical Engineering, 18(3), 439-451.

Đalic, I., Stevic, Z., Karamasa, C., \& Puska, A. (2020b). A novel integrated fuzzy PIPRECIAinterval rough SAW model: green supplier selection. Decision Making: Applications in Management and Engineering, 3(1), 126-145.

Dobrosavljević, A., Urošević, S., Vuković, M., Talijan, M., \& Marinković, D. (2020). Evaluation of process orientation dimensions in the apparel industry. Sustainability, 12(10), 4145.

Egan, D. J., \& Nield, K. (2000). Towards a theory of intraurban hotel location. Urban Studies, 37(3), 611-621.

Fang, L., Li, H., \& Li, M. (2019). Does hotel location tell a true story? Evidence from geographically weighted regression analysis of hotels in Hong Kong. Tourism Management, 72, 78-91.

Farahani, R. Z., Asgari, N., Heidari, N., Hosseininia, M., \& Goh, M. (2012). Covering problems in facility location: A review. Computers $\mathcal{E}$ Industrial Engineering, 62(1), 368-407.

Ghenai, C., Albawab, M., \& Bettayeb, M. (2020). Sustainability indicators for renewable energy systems using multi-criteria decision-making model and extended SWARA/ARAS hybrid method. Renewable Energy, 146, 580-597.

Govindan, K., Rajendran, S., Sarkis, J., \& Murugesan, P. (2015). Multi criteria decision making approaches for green supplier evaluation and selection: a literature review. Journal of Cleaner Production, 98, 66-83.

Huang, J. H., \& Peng, K. H. (2012). Fuzzy Rasch model in TOPSIS: a new approach for generating fuzzy numbers to assess the competitiveness of the tourism industries in Asian countries. Tourism Management, 33(2), 456-465.

Ilgin, M.A., Gupta, S. M., \& Battaïa, O. (2015). Use of MCDM techniques in environmentally conscious manufacturing and product recovery: state of the art. Journal of Manufacturing Systems, 37, 746-758.

Jaukovic Jocic K., Jocic, G., Karabasevic, D., Popovic, G., Stanujkic, D., Zavadskas, E. K., \& Thanh Nguyen, P. (2020). A novel integrated PIPRECIA-interval-valued triangular fuzzy ARAS model: Elearning course selection. Symmetry, 12(6), 928.

Jeong, J.S., García-Moruno, L., Hernández-Blanco, J., \& Jaraíz-Cabanillas, F.J. (2014). An operational method to supporting siting decisions for sustainable rural second home planning in ecotourism sites. Land Use Policy, 41, 550-560.

Kalnins, A., \& Chung, W., (2004). Resource-seeking agglomeration: a study of market entry in the lodging industry. Strategic Management Journal, 25(7), 689-699. 
Karabašević, D., Stanujkić, D., \& Urošević, S. (2015). The MCDM Model for Personnel Selection Based on SWARA and ARAS Methods. Management, 20(77), 1820-0222.

Karabasevic, D., Zavadskas, E. K., Turskis, Z., \& Stanujkic, D. (2016). The framework for the selection of personnel based on the SWARA and ARAS methods under uncertainties. Informatica, 27(1), 49-65.

Karabašević, D. M., Maksimović, M. V., Stanujkić, D. M., Jocić, G. B., \& Rajčević, D. P. (2018). Selection of software testing method by using ARAS method. Tehnika, 73(5), 724-729.

Kaya, A.O., Kaya, T., \& Kahraman, C. (2013). A fuzzy approach to urban ecotourism site selection based on integrated Promethee III methodology. Journal of MultipleValued Logic and Soft Computing, 21(1/2), 89-111.

Keršulienė, V., \& Turskis, Z. (2011). Integrated fuzzy multiple criteria decision making model for architect selection. Technological and economic development of economy, 17(4), 645-666.

Krylovas, A., Zavadskas, E. K., Kosareva, N., \& Dadelo, S. (2014). New KEMIRA method for determining criteria priority and weights in solving MCDM problem. International Journal of Information Technology Decision Making, 13(06), 1119-1133.

Lee, S. K., \& Jang, S. (2011). Room rates of U.S. Airport hotels: Examining the dual effects of proximities. Journal of Travel Research, 50(2), 186-197.

Lewis, R. C., \& Chambers, R. E. (1989). Marketing Leadership in Hospitality. New York: Van Nostrand Reinhold.

Li, M., Fang, L., Huang, X., \& Goh, C. (2015). A spatial-temporal analysis of hotels in urban tourism destination. International Journal of Hospitality Management, 45, 34-43.

Liu, C. H., Tzeng, G. H., \& Lee, M.H. (2012). Improving tourism policy implementation the use of hybrid MCDM models. Tourism Management, 33(2), 413-426.

Luo, H., \& Yang, Y. (2016). Intra-metropolitan location choice of star-rated and non-rated budget hotels: The role of agglomeration economies. International Journal of Hospitality Management, 59, 72-83.

Marco-Lajara, B., Claver-Cortés, E., Úbeda-García, M., \& Zaragoza-Sáez, P. D. C. (2016). Hotel performance and agglomeration of tourist districts. Regional Studies, 50(6), 1016-1035.

Marco-Lajara, B., del Carmen Zaragoza-Saez, P., Claver-Cortés, E., Úbeda-García, M., \& García-Lillo, F. (2017). Tourist districts and internationalization of hotel firms. Tourism Management, 61, 451-464.

Mardani, A., Jusoh MD, A., Nor, K., Khalifah, Z., Zakwan, N., \& Valipour, A., (2015). Multiple criteria decision-making techniques and their applications - a review of the literature from 2000 to 2014. Economic Research, 28(1), 516-571.

Marković, V., Stajić, L., Stević, Ž., Mitrović, G., Novarlić, B., \& Radojičić, Z. (2020). A novel integrated subjective-objective mcdm model for alternative ranking in order to achieve business excellence and sustainability. Symmetry, 12(1), 164.

Memis, S., Demir, E., Karamaşa, Ç., \& Korucuk, S. (2020). Prioritization of road transportation risks: An application in Giresun province. Operational Research in Engineering Sciences: Theory and Applications, 3 (2), 111-126.

Molina-Azorin, J. F., Pereira-Moliner, J., \& Claver-Cortés, E. (2010). The importance of the firm and destination effects to explain firm performance. Tourism Management, 31(1), 22-28.

Nedeljković, M., Puška, A., Doljanica, S., Virijević Jovanović, S., Brzaković, P., Stević, Ž., \& Marinkovic, D. (2021). Evaluation of rapeseed varieties using novel integrated fuzzy PIPRECIA-Fuzzy MABAC model. Plos one, 16(2), e0246857. 
Nevsehir Provincial Directorate of Culture and Tourism. (2019). Cappadocia accommodation reports, 2019, Nevsehir.

Nweze, S., \& Achebo, J. (2021). Comparative enhancement of mild steel weld mechanical properties for better performance using COPRAS-ARAS Method. European Journal of Engineering and Technology Research, 6(2), 70-74.

Pan, C. M. (2002). Market concentration ratio analysis of the international tourist hotel industry in Taipei area. Tourism Management Research, 2(2), 57-66.

Panahi, H., Mamipour, S., \& Nazari, K. (2015) Tourism and economic growth: a timevarying parameter approach. Anatolia, 26(2), 173-185.

Peiró-Signes, A., Segarra-Oña, M. D. V., Miret-Pastor, L., \& Verma, R. (2014). The effect of tourism clusters on US hotel performance. Cornell Hospitality Quarterly, 56(2), 155167.

Popovic, G., \& Mihajlovic, D., (2018). An MCDM approach to tourism projects evaluation: The Upper Danube Basin case. 3rd International Thematic Monograph - Thematic Proceedings: Modern Management Tools and Economy of Tourism Sector in Present Era, 129-141.

Popovic, G., Stanujkic, D., Brzakovic, M., \& Karabasevic, D. (2019). A multiple-criteria decision-making model for the selection of a hotel location. Land use policy, 84, 4958.

Puciato, D. (2016). Attractiveness of municipalities in South-Western Poland as determinants for hotel chain investments. Tourism Management, 57, 245-255.

Pulido-Fernández, J. I., Cárdenas-García, P. J., \& Sánchez-Rivero, M. (2014) Tourism as a tool for economic development in poor countries. Turizam: međunarodni znanstvenostručni časopis, 62(3), 309-322.

Rigall-I-Torrent, R., Fluvià, M., Ballester, R., Saló, A., Ariza, E., \& Espinet, J. M. (2011). The effects of beach characteristics and location with respect to hotel prices. Tourism Management, 32(5), 1150-1158.

Rivers, M. J., Toh, R. S., \& Alaoui, M. (1991). Frequent-stayer programs: the demographic, behavioural, and attitudinal characteristics of hotel steady sleepers. Journal of Travel Research, 30 (2), 41-45.

Sa, M. L. L., Choon-Yin, S., Chai, Y. K., \& Joo, J. H. A. (2020). Knowledge creation process, customer orientation and firm performance: Evidence from small hotels in Malaysia. Asia Pacific Management Review, 25(2), 65-74.

Shirouyehzad, H., Lotfi, F. H., Arabzad, S. M., \& Dabestani, R., (2013). An AHP/DEA ranking method based on service quality approach: a case study in hotel industry. International Journal of Production Quality Management, 11(4), 434-445.

Shoval, N., \& Cohen-Hattab, K. (2001). Urban hotel development patterns in the face of political shifts. Annals of Tourism Research, 28(4), 908-925.

Shoval, N., McKercher, B., Ng, E., \& Birenboim, A. (2011). Hotel location and tourist activity in cities. Annals of Tourism Research, 38(4), 1594-1612.

Sim, J., Mak, B., \& Jones, D. (2006). A model of customer satisfaction and retention for hotels. Journal of Quality Assurance in Hospitality \& Tourism, 7(3), 1-23.

Stanujkic, D., Kazimieras Zavadskas, E., Karabasevic, D., Smarandache, F., \& Turskis, Z., (2017). The use of the pivot pairwise relative criteria importance assessment method for determining the weights of criteria. Romanian Journal of Economic, 20(4), 116-133.

Stanujkic, D., \& Karabasevic, D. (2018).An extension of the WASPAS method for decisionmaking problems with intuitionistic fuzzy numbers: a case of website evaluation. Operational Research in Engineering Sciences: Theory and Applications, 1(1), 29-39. 
Stanujkic, D., Karabasevic, D., Zavadskas, E. K., Smarandache, F., \& Cavallaro, F. (2019). An approach to determining customer satisfaction in traditional Serbian restaurants. Entrepreneurship and Sustainability Issues, 6(3), 1127-1138.

Stevic, Z., Stjepanovic, Z., Bozickovic, Z., Das, D. K., \& Stanujkic, D. (2018). Assessment of conditions for implementing information technology in a warehouse system: a novel fuzzy PIPRECIA method. Symmetry, 10 (11), 586.

Stević, Ž., Karamaşa, Ç., Demir, E., \& Korucuk, S. (2021). Assessing sustainable production under circular economy context using a novel rough-fuzzy MCDM model: a case of the forestry industry in the Eastern Black Sea region. Journal of Enterprise Information Management. https://doi.org/10.1108/JEIM-10-2020-0419

Tomasevic, M., Lapuh, L., Stevic, Z., Stanujkic, D., \& Karabasevic, D. (2020). Evaluation of criteria for the implementation of high-performance computing (HPC) in Danube Region countries using fuzzy PIPRECIA method. Sustainability, 12 (7), 3017.

Urtasun, A., \& Gutiérrez, I. (2006). Hotel location in tourism cities: Madrid 1936-1998. Annals of Tourism Research, 33(2), 382-402.

Vesković, S., Stević, Ž., Stojić, G., Vasiljević, M., \& Milinković, S. (2018). Evaluation of the railway management model by using a new integrated model DELPHISWARAMABAC. Decision Making: Applications in Management and Engineering, 1(2), 34-50,

Veskovic, S., Milinkovic, S., Abramovic, B., \& Ljubaj, I. (2020). Determining criteria significance in selecting reach stackers by applying the fuzzy PIPRECIA method. Operational Research in Engineering Sciences: Theory and Applications, 3(1), 72-88.

Wu, C. S., Lin, C. T., \& Lee, C., (2010). Optimal marketing strategy: a decision-making with ANP and TOPSIS. International Journal of Production Economics, 127(1), 190-196.

Yang, Y., Luo, H., \& Law, R. (2014). Theoretical, empirical, and operational models in hotel location research. International Journal of Hospitality Management, 36, 209-220.

Yang, Y., Wong, K. K., \& Wang, T. (2012). How do hotels choose their location? Evidence from hotels in Beijing. International journal of hospitality management, 31(3), 675-685.

Yazdani, M., Chatterjee, P., Pamucar, D., \& Abad, M.D. (2019). A risk-based integrated decision-making model for green supplier selection. Kybernetes, 49(4), 1229-1252.

Zavadskas, E. K., \& Turskis, Z. (2010). A new additive ratio assessment (ARAS) method in multicriteria decision-making. Technological and Economic Development of Economy, 16(2), 159-172.

Zavadskas, E. K., Turskis, Z., \& Kildienè, S. (2014). State of art surveys of overviews on MCDM/MADM methods. Technological and Economic Development of Economy, 20(1), 165-179. 